\title{
THE EFFECTS OF DIFFERENT SOLVENTS ON BIOACTIVE METABOLITES AND "IN VITRO" ANTIOXIDANT AND ANTI-ACETYLCHOLINESTERASE ACTIVITY OF GANODERMA LUCIDUM FRUITING BODY AND PRIMORDIA EXTRACTS
}

\author{
Darija Cör ${ }^{1}$, Tanja Botić ${ }^{1}$, Željko Knez $^{1 *}$, Andrej Gregori ${ }^{2}$, Franc Pohleven ${ }^{3}$ \\ ${ }^{1}$ University of Maribor, Laboratory for Separation Processes and Product Design, \\ Faculty of Chemistry and Chemical Engineering, Smetanova 17, 2000 Maribor, Slovenia \\ ${ }^{2}$ Institute for Natural Sciences, Ulica bratov Učakar 108, 1000 Ljubljana, Slovenia, \\ MycoMedica d.o.o. Podkoren 72, 4280 Kranjska Gora, Slovenia \\ ${ }^{3}$ University of Ljubljana, Biotechnical Faculty, Department of Wood Technology, Rožna dolina, \\ Cesta VIII/34, 1000 Ljubljana, Slovenia \\ zeljko.knez@um.si
}

It is known that the lingzhi mushroom Ganoderma lucidum (Fr.) Karst produces various, bioactive metabolites. The objective of this study was to evaluate the antioxidant activity and acetylcholinesterase inhibitory activity of various extracts obtained from G. lucidum fruiting body and primordium, which is the initial stage of the mushroom's fruiting body. Classical extraction of G. lucidum fruiting bodies and primordia using different solvents (water, methanol, acetone, ethanol and hexane) at two temperatures (at $25{ }^{\circ} \mathrm{C}$ and at the boiling point of the solvent) was performed.

The influence of a solvent on the extraction yields and afterwards on the activity of the extract was observed. The extracts are rich in phenols, polysaccharides and proteins. The highest yield of $23.30 \%$ was obtained after water extraction. The total phenolic content was between $9 \mathrm{mgGA} / \mathrm{g}$ and $74.36 \mathrm{mgGA} / \mathrm{g}$ for G. lucidum fruiting bodies extracts and from $11.16 \mathrm{mgGA} / \mathrm{g}$ to $103.32 \mathrm{mgGA} / \mathrm{g}$ for G. lucidum primordia extracts. The antioxidant activity using the $\mathrm{DPPH}^{*}$ free radical scavenging method was from $0.48 \%$ to $23.66 \%$ and from $5.32 \%$ to $54.57 \%$ for fruiting bodies and primordia extracts, respectively.

Assessment of acetylcholinesterase enzyme inhibition was carried out using a colorimetric method based on Ellman's reaction. Acetylcholinesterase enzyme inhibition (AChE inhibition) by G. lucidum fruiting bodies extracts was between $18.1 \%$ and $32.5 \%$. The highest AChE inhibitory activity of primordia extracts was $29.48 \%$. This is the first report of G. lucidum primordia extracts and their biological activity.

Keywords: extraction; antioxidant; phenols; anti-acetylcholinesterase

\section{ВЛИЈАНИЕ НА РАЗЛИЧНИ РАСТВОРУВАЧИ НА БИОАКТИВНИ МЕТАБОЛИТИ И IN VITRO АНТИОКСИДАЦИСКА И АНТИАЦЕТИЛХОЛИНЕСТЕРАЗНА АКТИВНОСТ НА ПЛОДНОТО ТЕЛО И ЕКСТРАКТИТЕ ОД ПРИМОРДИУМОТ НА GANODERMA LUCIDUM}

Добро е познато дека дабовата сјајница Ganoderma lucidum (Fr.) Karst произведува разни биоактивни метаболити. Целта на ова истражување беше да се процени антиоксидациската активност и ацетилхолинестеразната (AChE) инхибиторна активност на разни екстракти добиени од плодното тело и од примордиумот кој е почетната фаза на плодното тело на G. lucidum. Беше извршена класична екстракција од плодното тело и од примордиумот на G. lucidum со употреба на различни растворувачи (вода, метанол, ацетон, етанол и хаксан) на две температури (на $25^{\circ} \mathrm{C}$ и на температура на вриење на растворувачот).

Беше одредено влијанието на растворувачот врз приносот на екстракцијата, а потоа и врз активноста на екстрактот. Екстрактите беа богати со феноли, полисахариди и протеини. Највисок принос од 23,30\% беше добиен при екстракција со вода. Вкупната содржина на фенолите беше 
меѓу $9 \mathrm{mgGA} / \mathrm{g}$ и 74,36 mgGA/g за екстрактите од плодното тело и од $11,16 \mathrm{mgGA} / \mathrm{g}$ до 103,32 $\mathrm{mgGA} / \mathrm{g}$ за екстрактите од примордиумот. Антиоксидациската активност со методот на прибирање на радикали со употреба на DPPH* се движеше од $0,48 \%$ до $23,66 \%$ за екстрактите од плодното тело и од $5,32 \%$ до $54,57 \%$ за екстрактите од примордиумот.

Процената на инхибицијата на ензимот $\mathrm{AChE}$ беше извршена со колориметриски метод со реакцијата на Ellman. Инхибицијата се движеше од $18,1 \%$ до $32,5 \%$ за екстрактите од плодното тело. Највисока инхибиција на екстрактите од примордиумот изнесуваше $29,48 \%$. Ова е прво истражување на екстрактите од примордиумот на G. lucidum и на нивната биолошка активност.

Клучни зборови: екстракција; антиоксидациско средство; феноли; ацетилхолинестераза

\section{INTRODUCTION}

Ganoderma lucidum (Fr.) Karst is a member of the mushroom family Polyporaceae and has been used in complementary medicine for over 2000 years $[1,2]$. G. lucidum develops from a nodule, or pinhead, less than two millimeters in diameter, called a primordium, which is typically found on or near the surface of the substrate. It takes approximately 25 days from primordium formation to the development of a mature fruiting body that is ready for harvest. Spores are the mushroom's reproductive cells formed from hymenium of G. lucidum after the fruiting bodies become mature [1].

The mycelia, mature fruiting body and spores of G. lucidum contain over 400 different bioactive compounds, including triterpenoids, polysaccharides, nucleotides, sterols, steroids, fatty acids, proteins/peptides, and trace elements which have been reported to have a number of medicinal effects [3, 4] such as immunomodulation, antitumor [5, 6] anti-atherosclerotic [7], anti-inflammatory, anti-microbial [8], hypolipidemic [9], hepatoprotective [10], anti-diabetic, anti-androgenic, anti-angiogenic, anti-herpetic, anti-oxidative and radical-scavenging, anti-aging [11], hypoglycemic [12] and anti-ulcer properties [13].

With aging, various pathological conditions and chronic diseases develop as a result of oxidative stress. The attack of free radicals on biomolecules, (lipids, proteins and DNA) eventually leads to many chronic diseases such as atherosclerosis, cancer, diabetes, rheumatoid arthritis, post-ischemic perfusion injury, myocardial infarction, cardiovascular diseases, chronic inflammation, stroke and septic shock, aging and other degenerative diseases in humans [14]. The use of strong radical scavengers such as antioxidants may potentially delay neurodegeneration in diseases such as Parkinson's, Huntington's, amyotrophic lateral sclerosis and Alzheimer's $[15,16]$. One of the most important strategies for the treatment of the neurodegenerative disorder Alzheimer's disease is to control the levels of acetylcholine in the brain through the inhibition of acetylcholinesterase (AChE) [17]. Many synthetic chemicals such as butylated hydroxyanisole (BHA), butylated hydroxytoluene (BHT), tert-butylhydroquinone (TBHQ) and propyl gallate (PG) are being used as strong radical scavengers; there is, however, growing interest in dietary antioxidants contained in many foods because of their natural origin and relative safety [14]. Among the sources of natural derived antioxidants, edible mushrooms such as $G$. lucidum are receiving attention as a potential commercial source of antioxidants at present $[18,19]$.

The antioxidant activity of G. lucidum extracts has been found to be correlated to their polysaccharide content as well as to their total phenolic contents [20]. In addition to phenols and polysaccharides, bioactive proteins from $G$. lucidum have been reported as antioxidants [21], [22]. Hasnat demonstrated the potential of G. lucidum extract as a valuable source of antioxidants exhibiting antiacetylcholinesterase activity [23].

In past studies, we observed that extracts obtained from G. lucidum fruiting bodies using supercritical carbon dioxide or hot water under different extraction conditions greatly vary in their bioactive capacities [24, 25].

Recently published genomes have revealed the full potential of G. lucidum as a source of biologically active compounds [26]. The authors studied variations in gene expression and triterpenoid content across three developmental stages of $G$. lucidum: areal mycelia, primordium and fruiting body. The results of a later study showed that significant numbers of genes $(4,668)$ are up- or downregulated during at least one of the developing stage transitions. Further, triterpenoid content markedly increased in the primordium; however, their biological activity was not evaluated. New findings demonstrate that the primordium of $G$. lucidum has been overlooked in terms of being a source of bioactive compounds.

Therefore, the aim of our investigation was to provide some insight into the chemical composition as well as the bioactivity (antioxidant and antiAChE) of extracts obtained from G. lucidum 
primordia and fruiting bodies using various conventional solvents. This is one of the first reports describing G. lucidum primordium as a source of biologically active phenols, polysaccharides, fatty acids and proteins.

\section{MATERIALS AND METHODS}

\subsection{Mushroom material}

G. lucidum fruiting bodies (GL) and its primordium (GL-P) were obtained from MycoMedica d.o.o. (Podkoren, Slovenia). Coomassie brilliant blue (CAS Number: 6104-58-1), bovine serum albumin $(\geqslant 96 \%)$ (CAS Number: 9048-46-8), phenol $(\geqslant 99.9 \%)$ (CAS Number: 108-95-2), glucose $(\geqslant 98 \%)$ and sodium carbonate $(\geqslant 99.9 \%)$ (CAS Number 497-19-8) were purchased from SigmaAldrich (Slovenia). Gallic acid $(\geqslant 98 \%)$ (CAS Number: 149-91-7) was purchased from Fluka (Germany). Sulfuric acid (99.99\%) and FolinCiocalteau phenol reagent were purchased from Merck (Germany). Hexane $(\geqslant 95 \%)$ (CAS Number: 110-54-3) and ethanol ( $\geqslant 99.9 \%$ ) (CAS Number: 64-17-5) were purchased from Carlo Erba (Ita- ly) and methanol ( $\geqslant 99.8 \%$ ) (CAS Number: 67-561) was purchased from J. T. Baker Chemicals (Netherlands).

\subsection{Extraction procedures}

\subsubsection{Extraction of phenolic compounds}

G. lucidum fruiting bodies (GL) and its primordia (GL-P) were lyophilized, crushed using liquid nitrogen, and milled. Two types of extraction, hot $(\mathrm{H})$ (at the boiling point of the solvent) and cold (C) (at $25^{\circ} \mathrm{C}$ ) were performed using different types of solvents (distilled water $\left(\mathrm{H}_{2} \mathrm{O}\right)$, ethanol $(\mathrm{EtOH})$, acetone $(\mathrm{AcOH})$, methanol $(\mathrm{MeOH})$ and hexane (Hex)). $5 \mathrm{~g}$ of GL or GL-P material was introduced into a flask and $100 \mathrm{ml}$ of solvent was added. Extraction at the boiling temperature of the solvent was performed in a flask with a reflux condenser while extraction at $25{ }^{\circ} \mathrm{C}$ was carried out in a closed flask. Extraction time was 3 hours with constant stirring. After that, the extract solution was filtered and the filtrate was evaporated to remove the solvent. Extraction yield (\%) was determined as:

$$
Y(\%)=\frac{m(G L e x t / G L-P \text { ext }-\mathrm{H} / \mathrm{C}-\mathrm{EtOH} / \mathrm{AcOH} / \mathrm{MeOH} / \mathrm{Hex})}{m G L / G L-P} \cdot 100
$$

where:

$$
\begin{aligned}
& Y \\
& m \mathrm{GL}_{\text {ekst. }} / \mathrm{GL}-\mathrm{P}_{\text {ekst. }}-\mathrm{H} / \mathrm{C}-\mathrm{H}_{2} \mathrm{O} \\
& m \mathrm{GL}_{\text {ekst. }} / \mathrm{GL}-\mathrm{P}_{\text {ekst. }}-\mathrm{H} / \mathrm{C}-\mathrm{MeOH} \\
& m \mathrm{GL}_{\text {ekst. }} / \mathrm{GL}-\mathrm{P}_{\text {ekst. }}-\mathrm{H} / \mathrm{C}-\mathrm{EtOH} \\
& m \mathrm{GL}_{\text {ekst. }} / \mathrm{GL}-\mathrm{P}_{\text {ekst. }}-\mathrm{H} / \mathrm{C}-\mathrm{Ac} \\
& m \mathrm{GL}_{\text {ekst. }} / \mathrm{GL}-\mathrm{P}_{\text {ekst. }}-\mathrm{H} / \mathrm{C}-\mathrm{Hex} \\
& m(\mathrm{GL} /(\mathrm{GL}-\mathrm{P}))
\end{aligned}
$$

\subsubsection{Extraction of polysaccharides}

The polysaccharidic extracts were obtained using three different procedures: (1) by conventional extraction and purification of polysaccharides described by Villares et al. [27], (2) by hot water extraction and precipitation with ethanol as described by Skalicka-Woźniak et al. [28], in both
- extraction yield $(\%)$

- mass of fruiting body/primordia extract using $\operatorname{hot}(\mathrm{H}) / \operatorname{cold}(\mathrm{C})$ water for extraction $(\mathrm{g})$

- mass of fruiting body/primordia extract using $\operatorname{hot}(\mathrm{H}) / \operatorname{cold}(\mathrm{C})$ methanol $(\mathrm{g})$

- mass of fruiting body/primordia extract using $\operatorname{hot}(\mathrm{H}) / \operatorname{cold}(\mathrm{C})$ ethanol $(\mathrm{g})$

- mass of fruiting body/primordia extract using $\operatorname{hot}(\mathrm{H}) / \operatorname{cold}(\mathrm{C})$ acetone $(\mathrm{g})$

- mass of fruiting body/primordia extract using $\operatorname{hot}(\mathrm{H}) / \operatorname{cold}(\mathrm{C})$ hexane $(\mathrm{g})$

- mass of fruiting body (GL) and primordia (GL-P) raw material $(\mathrm{g})$

cases using $5 \mathrm{~g}$ of GL or GL-P, and (3) extraction with methanol ( $T=67.7^{\circ} \mathrm{C}$ and $p=1$ bar $)$, in order to remove phenolic compounds and other related molecules [27]. Then, the methanolic extract was filtered and residue of GL or GL-P was extracted with hot water $\left(T=100{ }^{\circ} \mathrm{C}\right)$. The water extract was filtered (filtrate 1) and the remaining solid material was extracted with an aqueous basic solution of 
$2 \% \mathrm{w} / \mathrm{v}$ of $\mathrm{NaOH}$ at $100{ }^{\circ} \mathrm{C}$. Again, the extract was filtered (filtrate 2) and GL or GL-P was discharged. Both filtrates were combined and proteins removed by precipitation with trifluoroacetic acid (TFA) $(20 \% \mathrm{w} / \mathrm{v})$. Then, proteins were separated by centrifugation.

Purified polysaccharidic extract of fruiting bodies in addition as - GL-PS ${ }_{\text {ext. }}-1$ and polysaccharidic extract of primordia in addition as GL-P-PS -1 were finally precipitated from the supernatant by the addition of EtOH in a 2:1 ratio $(\mathrm{v} / \mathrm{v})$. In the second procedure, GL or GL-P was extracted with $100 \mathrm{ml}$ of distilled water at $85^{\circ} \mathrm{C}$ for 6 hours with stirring. The crude hot water extracts were filtered and polysaccharidic extract of fruiting bodies (GL$\mathrm{PS}_{\text {ext. }}-2$ ) and polysaccharidic extract of primordia (GL-P-PS ext. -2$)$ were separated as described by Skalicka-Woźniak. Briefly, cold ethanol in a ratio of $3: 1 \mathrm{v} / \mathrm{v}$ was added to concentrated hot water extracts and polysaccharides were precipitated overnight at $+4{ }^{\circ} \mathrm{C}$. The precipitated polysaccharides were collected after centrifugation (in an Eppendorf $5804 \mathrm{R}$ refrigerated centrifuge) at $3100 \mathrm{rpm}$ for $10 \mathrm{~min}$.

\subsubsection{Extraction of proteins}

Five $g$ of GL or GL-P was extracted with 100 $\mathrm{ml}$ of methanol for 3 hours under constant stirring to remove phenolic compounds. After the hot water extraction of residue of GL or GL-P was performed, the extract was filtered and proteins removed from the filtrate using trifluoroacetic acid $(20 \% \mathrm{w} / \mathrm{v})$. Then, protein extract of fruiting bodies, hereafter GL-P ${ }_{\text {ext, }}$ and protein extract of primordial, hereafter GL-P-P ${ }_{\text {ext, }}$ was separated by centrifugation [27].

\subsection{Chemical content of extracts}

\subsubsection{Total phenol content}

The concentration of total phenols in the extracts was measured by UV spectrophotometry (Varian, USA), based on a colorimetric oxidation/reduction reaction. The total phenols were determined according to the Folin-Ciocalteau method (1927) with some modifications [29]. Briefly, all extracts were diluted in methanol at concentrations of $1 \mathrm{mg} \cdot \mathrm{ml}^{-1} .2 .5 \mathrm{ml}$ of Folin-Ciocalteau reagent (diluted with water at a 1:10 ratio) was mixed with $0.5 \mathrm{ml}$ of extract solution and $2.5 \mathrm{ml}$ of $\mathrm{Na}_{2} \mathrm{CO}_{3}(75$ $\mathrm{g} \cdot \mathrm{l}^{-1}$ ). Prepared samples were then thermostated in a water bath at $50{ }^{\circ} \mathrm{C}$ for $5 \mathrm{~min}$. After cooling, the absorbance was measured at $760 \mathrm{~nm}$. As a control, $0.5 \mathrm{ml}$ of methanol was used instead of the extract solution.
Quantification was determined based on the standard curve of gallic acid (GA). The amount (\%) of phenol content $\left(\mathrm{w}_{\mathrm{GA}}\right)$ was expressed as $\mathrm{mg}_{\mathrm{GA}}$ per gram $(\mathrm{g})$ of extract.

\subsubsection{Protein content}

The total protein content was measured using the Bradford method. Briefly, $100 \mathrm{mg}$ of Coomassie Brilliant Blue was mixed with $50 \mathrm{ml}$ of $95 \%$ ethanol, and $100 \mathrm{ml}$ of $85 \%(\mathrm{v} / \mathrm{v}) \mathrm{H}_{3} \mathrm{PO}_{4}$ solution was diluted with distilled water to 1 liter. The quantification was determined based on the standard curve of Bovine Serum Albumin (BSA). The calibration curve was in the range of $0.0 \mathrm{mg} \cdot \mathrm{ml}^{-1}$ to $1 \mathrm{mg} \cdot \mathrm{ml}^{-1}[30]$.

GL-P $\mathrm{P}_{\mathrm{ext}}$ or GL-P-P $\mathrm{ext}_{\text {was }}$ diluted with water to a concentration of $1 \mathrm{mg} \cdot \mathrm{ml}^{-1}$. An aliquot $(20 \mu \mathrm{l})$ was mixed with $1 \mathrm{ml}$ of Bradford reagent and the absorbance was measured at $595 \mathrm{~nm}$. Total protein content was expressed in mg of BSA per gram $(\mathrm{g})$ of extract (mg BSA $\cdot g^{-1}$ GL-P ext $_{\text {or }}$ GL-P-P ext $)$.

\subsubsection{Polysaccharide content}

Polysaccharide content was determined using the phenol-sulfuric acid method and D-glucose as standard [31]. Polysaccharidic extract solutions $\left(1 \mathrm{mg} \cdot \mathrm{ml}^{-1}\right)$ were prepared in distilled water. Then, $0.5 \mathrm{ml}$ of solution was mixed with $0.5 \mathrm{ml}$ of $5 \%$ aqueous phenol solution and $2.5 \mathrm{ml}$ of concentrated sulfuric acid. The mixture was stirred for 30 $\min$. The total sugar content was determined on the standard curve for glucose $\left(0.0047 \mathrm{mg} \cdot \mathrm{ml}^{-1}-0.15\right.$ $\mathrm{mg} \cdot \mathrm{ml}^{-1}$ ) at a wavelength of $490 \mathrm{~nm}$. The results were expressed as $\mathrm{mg}$ of glucose equivalents per gram of polysaccharidic extract dry weight.

\subsection{Biological activity of extracts}

\subsubsection{Scavenging effect}

on 1,1-diphenyl-2-picrylhydrazyl (DPPH) radicals

For the assay, $3.9 \mathrm{ml}$ of $0.06 \mathrm{mM}$ DPPH* radical (Sigma, CAS Number: 1898-66-4) was added to $0.1 \mathrm{ml}$ of G. lucidum fruiting body or primordia extract. The reaction mixture was vortexed and absorbance measured at $515 \mathrm{~nm}$ using a spectrophotometer with methanol as a control. The decrease in absorbance was monitored until the reaction reached a plateau. The $\mathrm{DPPH}^{*}$ free radical scavenging activity, expressed as a percentage of radical scavenging activity, was calculated as follows:

$$
\text { DPPH scavenging activity }(\%)=\frac{A_{0}-A_{s}}{A_{0}} \cdot 100
$$


where $\mathrm{A}_{0}$ is the absorbance of $0.06 \mathrm{mM}$ methanolic $\mathrm{DPPH}$ and $\mathrm{A}_{\mathrm{s}}$ is the absorbance of the reaction mixture after $30 \mathrm{~min}[32]$.

\subsubsection{Anti-acetylcholinesterase activity}

The inhibition of acetylcholinesterase (AChE) was measured according to the Ellman method (1961), using acetylthiocholine iodide $(1 \mathrm{mM})$ as the substrate in $100 \mathrm{mM}$ potassium phosphate buffer, $\mathrm{pH}$ 7.4, at $25^{\circ} \mathrm{C}$, and electric eel $\mathrm{AChE}$ as the source of enzyme (6.25 U. $\mathrm{ml}^{-1}$, Sigma) (Ellman et al. 1961) [33]. The hydrolysis of acetylthiocholine iodide was measured on a Kinetic Microplate Reader (Varian, USA) at $405 \mathrm{~nm}$. The concentration of the extracts was $1 \mathrm{mg} / \mathrm{ml}$ and AChE inhibition was monitored for $5 \mathrm{~min}$. All readings were corrected for their appropriate controls, and a run with only acetylthi- ocholine chloride served as a positive control assay. Galathamine, a common AChE inhibitor, was used as a control. Every measurement was repeated at least two times.

\section{RESULTS AND DISCUSSION}

\subsection{Conventional extraction using conventional solvents}

\subsubsection{Yield of extraction using conventional solvents}

Extraction yield $(\eta)$ using different types of solvents (distilled water $\left(\mathrm{H}_{2} \mathrm{O}\right)$, methanol $(\mathrm{MeOH})$, ethanol (EtOH), acetone (Ac) and hexane (Hex)) is presented in Table 1.

\section{Table 1}

Yield (\%) after extraction of $G$. lucidum fruiting body $(G L)$ and G. lucidum primordia (GL-P.)

\begin{tabular}{|c|c|c|c|c|c|c|}
\hline \multirow{2}{*}{ Solvent } & \multicolumn{3}{|c|}{$\begin{array}{c}\mathrm{GL}-\text { fruiting body } \\
Y(\%)\end{array}$} & \multicolumn{3}{|c|}{$\begin{array}{c}\text { GL-P - primordia } \\
Y(\%)\end{array}$} \\
\hline & $\begin{array}{c}\text { Cold (C) } \\
\mathrm{T}=25^{\circ} \mathrm{C}\end{array}$ & $\begin{array}{c}\text { Hot }(\mathrm{H}) \\
\text { at } \mathrm{T}_{\mathrm{B}}\end{array}$ & $T_{\mathrm{B}}\left({ }^{\circ} \mathrm{C}\right)$ & $\begin{array}{c}\text { Cold (C) } \\
\mathrm{T}=25^{\circ} \mathrm{C}\end{array}$ & $\begin{array}{c}\text { Hot }(H) \\
\text { at } T_{B}\end{array}$ & $T_{\mathrm{B}}\left({ }^{\circ} \mathrm{C}\right)$ \\
\hline $\mathrm{H}_{2} \mathrm{O}$ & 19.13 & 23.30 & $100^{\circ} \mathrm{C}$ & 20.10 & 24.15 & $100^{\circ} \mathrm{C}$ \\
\hline $\mathrm{MeOH}$ & 9.20 & 9.33 & $64.7^{\circ} \mathrm{C}$ & 12.05 & 14.98 & $64.7^{\circ} \mathrm{C}$ \\
\hline $\mathrm{EtOH}$ & 6.16 & 4.22 & $78.4^{\circ} \mathrm{C}$ & 4.94 & 6.15 & $78.4^{\circ} \mathrm{C}$ \\
\hline Ac & 3.58 & 3.15 & $56^{\circ} \mathrm{C}$ & 5.02 & 6.05 & $56{ }^{\circ} \mathrm{C}$ \\
\hline Hex & 1.42 & 2.40 & $69^{\circ} \mathrm{C}$ & 0.95 & 3.11 & $69^{\circ} \mathrm{C}$ \\
\hline
\end{tabular}

$* T_{\mathrm{B}}-$ boiling temperature of a solvent

When water was used as a solvent, the highest yield $(23.30 \%)$ was obtained. The yield decreased in the order of $\mathrm{H}_{2} \mathrm{O}>\mathrm{MeOH}>\mathrm{EtOH}>\mathrm{Ac}>\mathrm{Hex}$. Only slight changes in the total yield were observed in the comparison of hot/cold extraction procedures. Higher extraction yield does not necessarily mean higher medicinal activity of the extracts.

The relative polarity of the solvents used in the present study increases in the order of hexane $\mathrm{Hex}<\mathrm{Ac}<\mathrm{EtOH}<\mathrm{MeOH}<\mathrm{H}_{2} \mathrm{O}$. Extraction efficiency also increases in that order. The polarity of the solvent thus greatly influences the extraction yields. Higher temperatures usually lead to higher yields of extraction. However, in our study, the polarity of the solvent shows a greater influence on yield. Solvents such as methanol, ethanol and acetone are often used for the extraction of phenolic compounds, while hexane is more often used for the isolation of fatty acids. The yield in hexane solvent was the lowest. This corresponds to the fact that $G$. lucidum contains very low amounts of fatty acids
[34]. In general, the average yields for GL-P are slightly higher than those for GL. Mushrooms store components in the initial phase, which are needed for their further development, and we expected these to show slightly higher extraction efficiency values. We conclude that many of the components such as GL and GL-P are polar and that non-polar components are significantly less common.

\subsubsection{Total phenols in extracts obtained with conventional solvents}

The contents of total phenols in extracts obtained from $G$. lucidum fruiting bodies $\left(\mathrm{GL}_{\mathrm{ext}}\right)$ and G. lucidum primordia (GL- $\mathrm{P}_{\mathrm{ext}}$ ) using various conventional solvents are presented in Figure 1 and Figure 2, respectively.

The concentration of total phenolic compounds in $\mathrm{GL}_{\text {ext. }}$ ranged from $9.01 \mathrm{mg}_{\mathrm{GA}} \cdot \mathrm{g}_{\mathrm{ext}}{ }^{-1}$ to $74.36 \mathrm{mg}_{\mathrm{GA}} \cdot \mathrm{g}_{\mathrm{ext}}{ }^{-1}$, depending on solvent selection and temperature during the extraction process. The 
highest concentration of phenolic compounds is $74.36 \mathrm{mg}_{\mathrm{GA}} \cdot \mathrm{g}_{\mathrm{ext}}{ }^{-1} \mathrm{EtOH} \mathrm{GL}_{\mathrm{ext}}$, decreasing in the order $\mathrm{EtOH}>\mathrm{MeOH}>\mathrm{H}_{2} \mathrm{O}>\mathrm{AcOH}>\mathrm{Hex}$. The influence of temperature during the extraction process on the total amount of phenols in $\mathrm{GL}_{\text {ext }}$ was noticed. Extraction with EtOH at its boiling point resulted in $74.36 \mathrm{mg}_{\mathrm{GA}} \cdot \mathrm{g}_{\mathrm{ext}}{ }^{-1} \mathrm{GL}_{\mathrm{ext}}$ while the amount was $65.72 \mathrm{mg}_{\mathrm{GA}} \cdot \mathrm{g}_{\mathrm{ext}}{ }^{-1}$ when $\mathrm{EtOH}$ at $25^{\circ} \mathrm{C}$ was used. The effect of extraction temperature on total phenolic content was also noticed in the case of $\mathrm{AcOH}$ (Fig. 1). However, when $\mathrm{MeOH}$ was used, a higher content of total phenols, 52.11 $\mathrm{mg}_{\mathrm{GA}} / \mathrm{g}_{\mathrm{ext}}$, was obtained when extraction was performed at $25^{\circ} \mathrm{C}$, while performing extraction using $\mathrm{MeOH}$ at boiling point resulted in the production of $32.86 \mathrm{mg}_{\mathrm{GA}} \cdot \mathrm{g}_{\mathrm{ext}}{ }^{-1}$ in $\mathrm{GL}_{\mathrm{ext}}$. The effect of solvent type on total phenols in different mushrooms was previously studied by Tsai et al. [35], who noticed that the highest yield of phenolic compounds was in ethanol, which ranked second after water. Orhan et al. (2011) determined the total phenol content of ethanolic extracts in a number of mushroom species growing in Turkey [36]. The phenol content was in the range of $2.5 \mathrm{mg}_{\mathrm{GA}} \cdot \mathrm{g}_{\mathrm{ext}}^{-1}$ to 51.7 $\mathrm{mg}_{\mathrm{GA}} \cdot \mathrm{g}_{\mathrm{ext}}{ }^{-1}$.

Heleno et al. extracted G. lucidum from fruiting bodies with methanol : water $(80: 20)$ at $20{ }^{\circ} \mathrm{C}$ for 2 hours [37]. The total phenolic content was 28.64 $\mathrm{mg}_{\mathrm{GA}} \cdot \mathrm{g}_{\mathrm{ext}}{ }^{-1}$ in methanol/water extracts of the $G$. $l u$ cidum fruiting bodies. In our study, a two-fold higher concentration of total phenolic content at $25{ }^{\circ} \mathrm{C}$ was observed in $\mathrm{GL}_{\text {ext }}$ produced with methanol extraction.

Celik et al. determined a higher total phenol content (49.52 $\mathrm{mg}_{\mathrm{GA}} \cdot \mathrm{g}_{\mathrm{ext}}{ }^{-1}$ ) in G. lucidum ethanol extracts in comparison with methanol extracts obtained by Soxhlet extraction [38].

The influence of solvent type as well as temperature during the extraction process has an effect on the total phenol content in the $\mathrm{GL}_{\text {ext }} \mathrm{ob}-$ tained. There is no report on the influence of different types of solvents at different temperatures on G. lucidum phenol content.

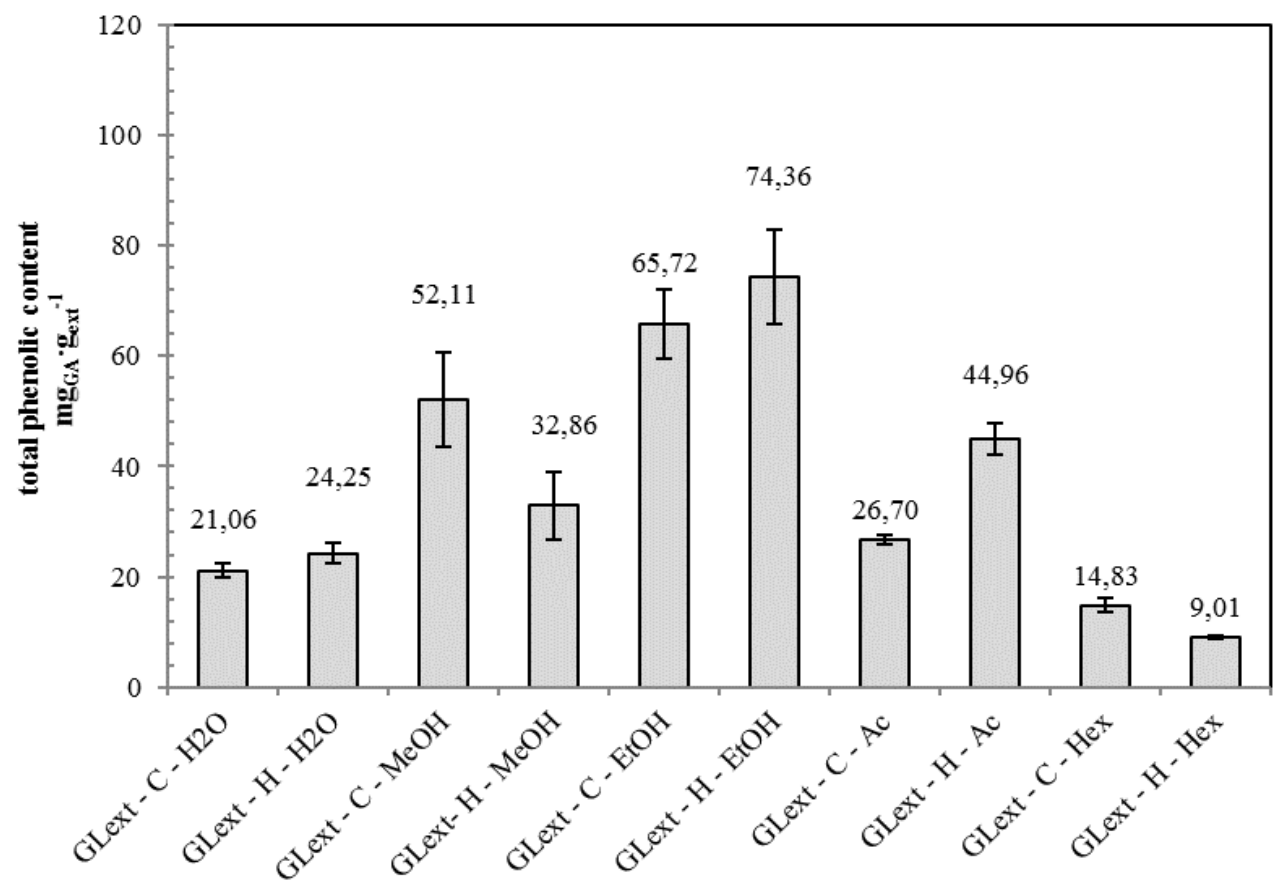

Fig. 1. Total phenol content $\left(w_{\mathrm{GA}}\right)$ in G. lucidum extracts $\left(\mathrm{GL}_{\text {ext. }}\right.$ ) obtained by hot (at boiling point)/cold (at $\left.25^{\circ} \mathrm{C}\right)(\mathrm{H} / \mathrm{C})$ extraction with different solvents $\left(\mathrm{H}_{2} \mathrm{O}, \mathrm{MeOH}, \mathrm{EtOH}, \mathrm{AcOH}, \mathrm{Hex}\right)$. The standard deviation is expressed as \pm value, from at least two replicates, where two independent experiments were performed.

The concentration of total phenolic compounds in GL-P $\mathrm{ext}_{1}$ ranged from $11.16 \mathrm{mg}_{\mathrm{GA}} \cdot \mathrm{g}_{\mathrm{ext}}{ }^{-1}$ to 103.32 $\mathrm{mg}_{\mathrm{GA}} \cdot \mathrm{g}_{\mathrm{ext}}{ }^{-1}$, depending on solvent type and extraction temperature (Figure 2). The highest yield of GL-P $\mathrm{P}_{\text {ext }}$ phenolic compounds, 103.32 $\mathrm{mg}_{\mathrm{GA}} \cdot \mathrm{g}_{\mathrm{ext}}{ }^{-1}$ was obtained with hot Ac. The concentration of phenolic compounds from GL-P $\mathrm{ext}_{\mathrm{ob}} \mathrm{Ob}$ tained using hot $(\mathrm{H})$ solvents decreased in the order of Ac $>\mathrm{EtOH}>\mathrm{H}_{2} \mathrm{O}=\mathrm{MeOH}$. Because of similar polarity, $46 \mathrm{mg}_{\mathrm{GA}} \cdot \mathrm{g}_{\mathrm{ext}}{ }^{-1} \mathrm{GL}-\mathrm{P}_{\mathrm{ext}}$ of phenols were obtained both when $(\mathrm{H}) \mathrm{MeOH}$ and $(\mathrm{H}) \mathrm{H}_{2} \mathrm{O}$ were used. The highest influence of extraction temperature on the amount of total phenols from GL- $\mathrm{P}_{\mathrm{ext}}$ was noticed when Ac was used. GL-P ${ }_{\text {ext }}$ obtained 
with $(\mathrm{H})$ Ac contained $103.32 \mathrm{mg}_{\mathrm{GA}} \cdot \mathrm{g}_{\mathrm{ext}}{ }^{-1}$, while $64.54 \mathrm{mg}_{\mathrm{GA}} \cdot \mathrm{g}_{\mathrm{ext}}{ }^{-1}$ of phenols were present in extract obtained with cold (C) Ac. (C) extraction generally resulted in a lower amount of phenolic compounds, except for the case of $\mathrm{MeOH}$ (Fig. 2). The expected phenolic compounds were not present in the extract obtained using hexane as a solvent.
From Figures 1 and 2, it can be seen that there is similar trend if we compare only temperatures using the same solvent type. In general, the amounts of total phenols in GL-P $\mathrm{P}_{\mathrm{ext}}$ are higher than in $\mathrm{GL}_{\text {ext }}$.

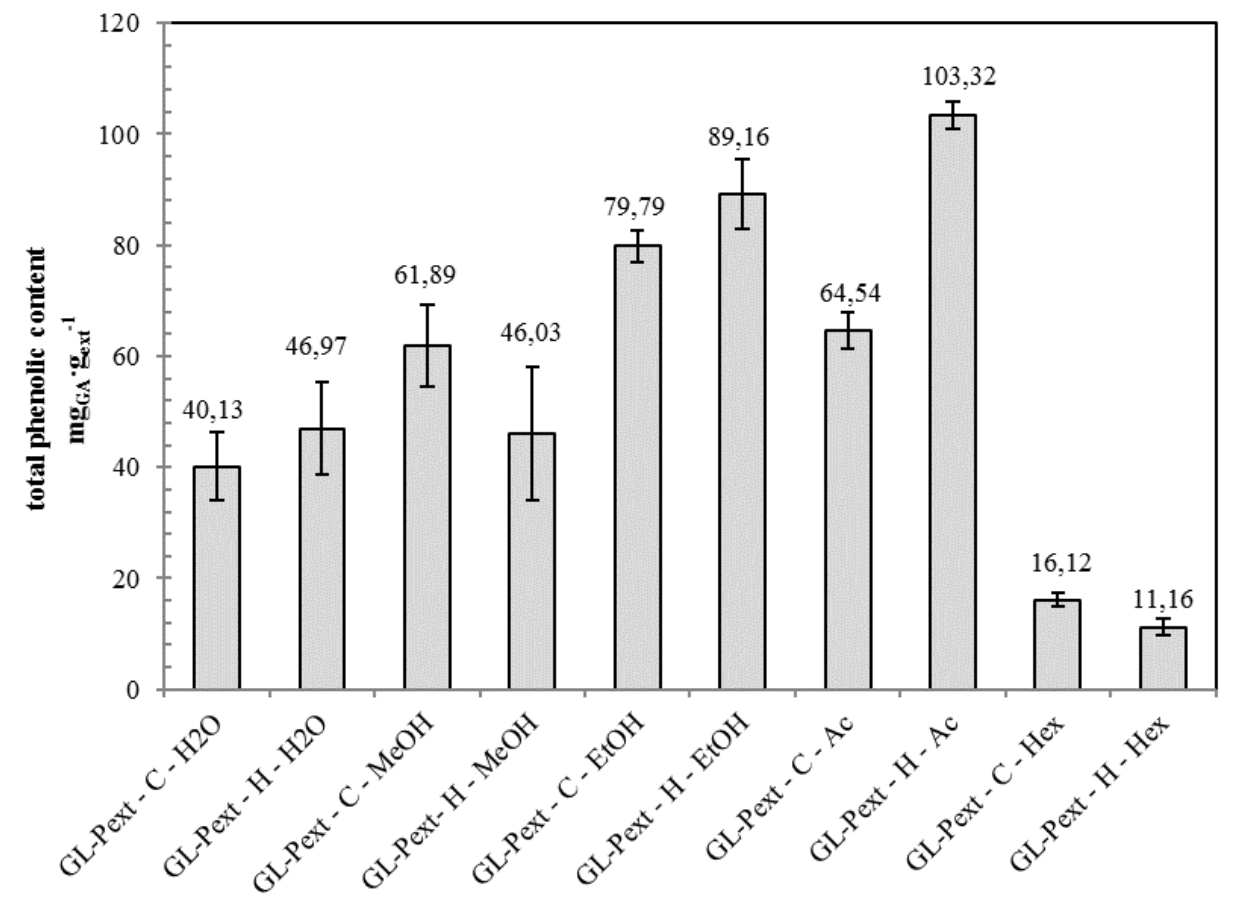

Fig. 2. The content of total phenols in extracts obtained from G. lucidum (GL-P $\mathrm{P}_{\mathrm{ext}}$ ) primordium. Data are presented as $\mathrm{mgGA} / \mathrm{g}$ GL- $\mathrm{P}_{\text {ext }}$ and are expressed as means \pm SD from two replicates. Extraction temperature: hot $(\mathrm{H})$ and cold $(\mathrm{C})$; extraction solvent: $\mathrm{H}_{2} \mathrm{O}, \mathrm{MeOH}, \mathrm{EtOH}, \mathrm{Ac}$ and $\mathrm{Hex}$.

\subsubsection{DPPH free radical scavenging activity of extracts obtained with conventional solvents}

The results of $\mathrm{DPPH}^{*}$ radical scavenging ac-

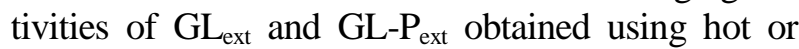
cold extraction are presented in Figure 3 and Figure 4 , respectively. The highest $\mathrm{DPPH}^{*}$ radical scavenging inhibitory activity was observed for hot $\mathrm{AcOH}$ $\left(\mathrm{GL}_{\mathrm{ext}}-\mathrm{H}-\mathrm{Ac}\right)$ at $23.66 \%$. DPPH* radical scavenging inhibitory activity for cold and hot $\mathrm{MeOH}$ and $\mathrm{EtOH}$ vary between $12.90 \%$ and $16.84 \%$ (Fig. 3).

In the present study, the highest total phenol contents did not result in the highest $\mathrm{DPPH}^{*}$ radical scavenging activity of the $\mathrm{GL}_{\text {ext }}$ obtained (Figs. 1 and 2). These results correspond to the observations of Orhan et al. [36].

In general, positive correlations were found between the total phenolic content and the DPPH free radical scavenging activities elicited (Fig. 2 and Fig. 4).

It can be seen from Figure 4 that the maximum inhibition of DPPH radicals occurs when hot acetone solvent is used, followed by hot ethanol, methanol, water and hexane. The values of inhibition of DPPH radicals by GL-P ext $_{\text {were significant- }}$ ly higher than $\mathrm{GL}_{\text {ext }}$.

The use of different solvents can result in the extraction of various types of metabolites from G. lucidum fruiting bodies and primordia, with varying radical scavenging activities. Furthermore, increased temperatures during the extraction process may result in denaturation and a reduction of the loss of ability to act as an antioxidant.

The lowest radical-scavenging activities were observed for the extracts obtained in Hex, which is mostly used for extraction of lipids; therefore, polar compounds with recognized high antioxidant capacity could not be obtained.

De Bruin et al. investigated the antioxidant properties of extracts obtained from Grifola gargal mushrooms, which are of the same order as our results [39]. 
If we compare the effect of temperature in the same solvent and different material, GL and GL-P can be seen to have similar trends. The reason for the higher values of inhibition of $\mathrm{DPPH}^{*}$ radicals in GL-P $\mathrm{P}_{\mathrm{ext}}$ is that in the early stage of fun- gus growth, it produces substances which are necessary for its growth. Thus, the contents of total phenols, as the values of the inhibition DPPH* radicals for GL-P $\mathrm{P}_{\mathrm{ext}}$, are higher than in $\mathrm{GL}_{\mathrm{ext}}$.

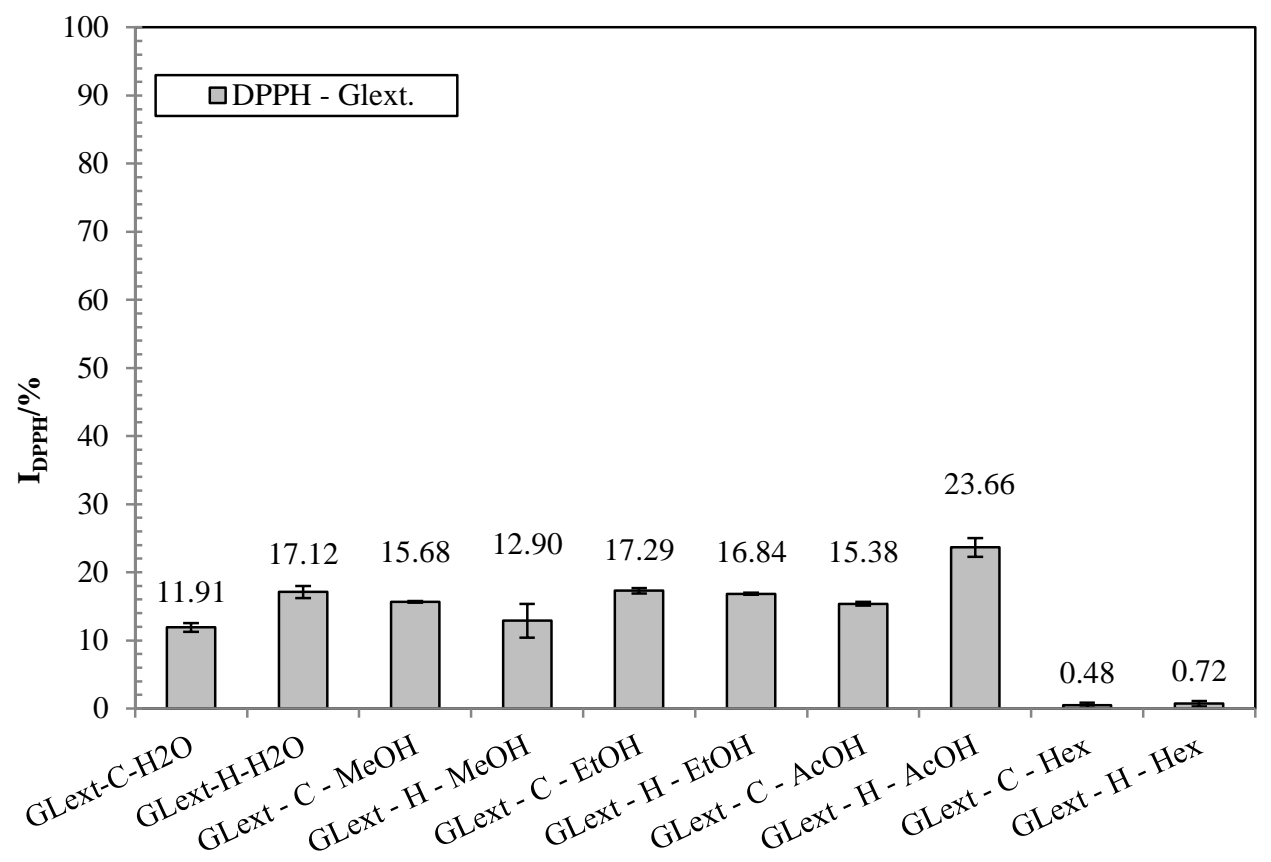

Fig. 3. DPPH radical scavenging activity of extracts obtained from G. lucidum fruiting body $\left(\mathrm{GL}_{\mathrm{ext}}\right)$. Data are expressed as inhibition in \%. Extraction temperature: hot - at boiling point of the solvent $(\mathrm{H})$, and cold - at $25^{\circ} \mathrm{C}(\mathrm{C})$; extraction solvent: $\mathrm{H}_{2} \mathrm{O}, \mathrm{MeOH}$,

$\mathrm{EtOH}, \mathrm{Ac}$ and Hex. Data are means \pm SD from two replicates, where two independent experiments were performed.

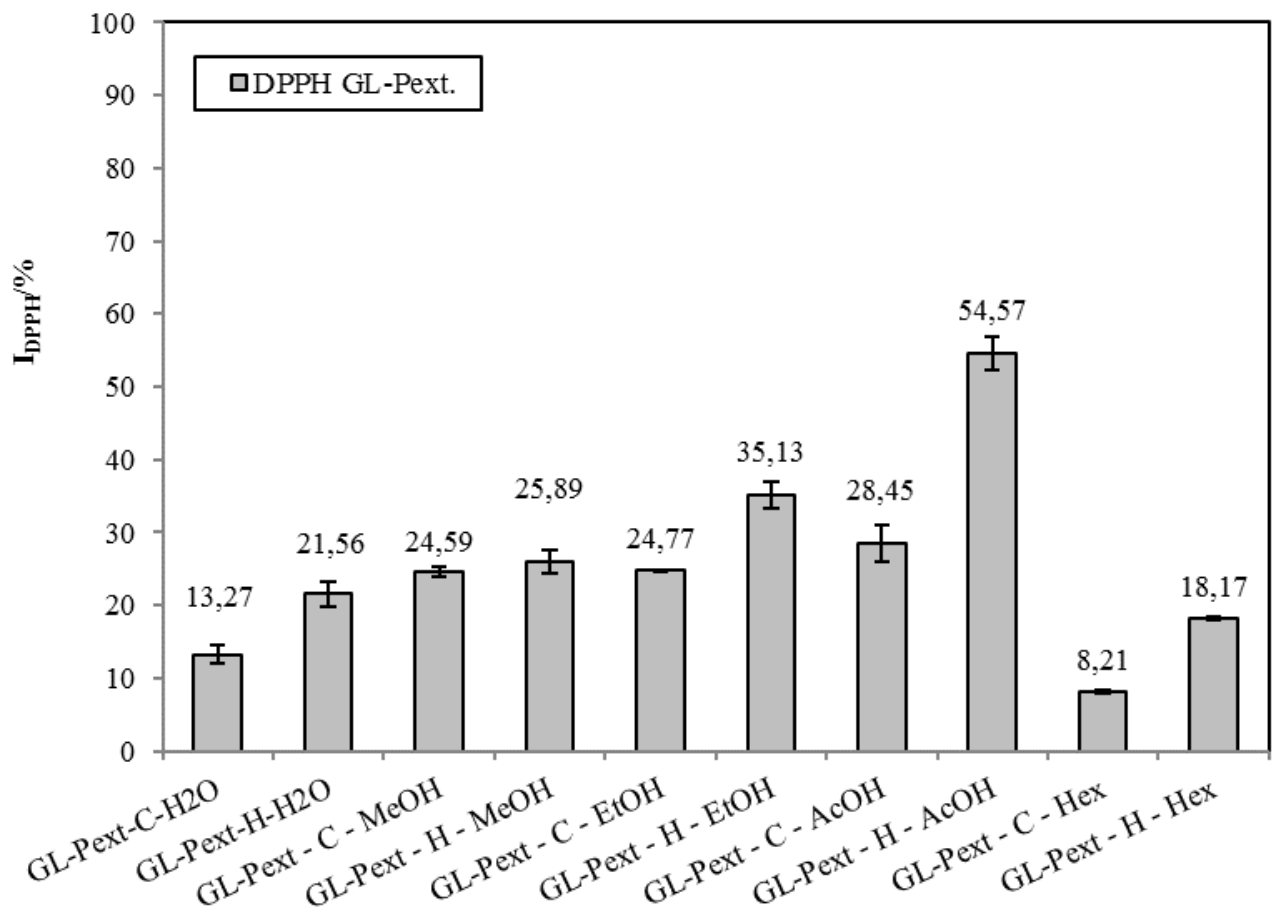

Fig. 4. DPPH radical scavenging activity of extracts obtained from $G$. lucidum primordia (GL-P $\left.\mathrm{P}_{\mathrm{ext}}\right)$. Data are expressed as inhibition in \%. Extraction temperature: hot - at boiling point of the solvent $(\mathrm{H})$ and cold - at $25{ }^{\circ} \mathrm{C}(\mathrm{C})$; extraction solvent: $\mathrm{H}_{2} \mathrm{O}, \mathrm{MeOH}$ $\mathrm{EtOH}, \mathrm{Ac}$ and Hex. Data are means \pm SD from two replicates, where two independent experiments were performed. 


\subsubsection{Inhibition of acetylcholinesterase (AChE) by extracts obtained with conventional solvents}

Since antioxidants play an important role in the protection against aging processes and neurodegenerative diseases such as Alzheimer's disease (AD), the ability of $\mathrm{GL}_{\mathrm{ext}}$ and GL-P $\mathrm{ext}_{\mathrm{t}}$ to inhibit the
AChE enzyme was determined. Both $\mathrm{GL}_{\text {ext. }}$ and

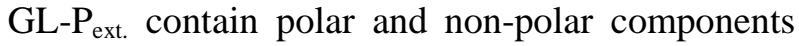
which have the capability to inhibit AChE.

The AChE inhibitory activities of $\mathrm{GL}_{\mathrm{ext}}$ and

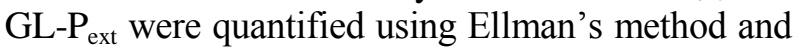
the results are summarized in Figure 5 and Figure 6.

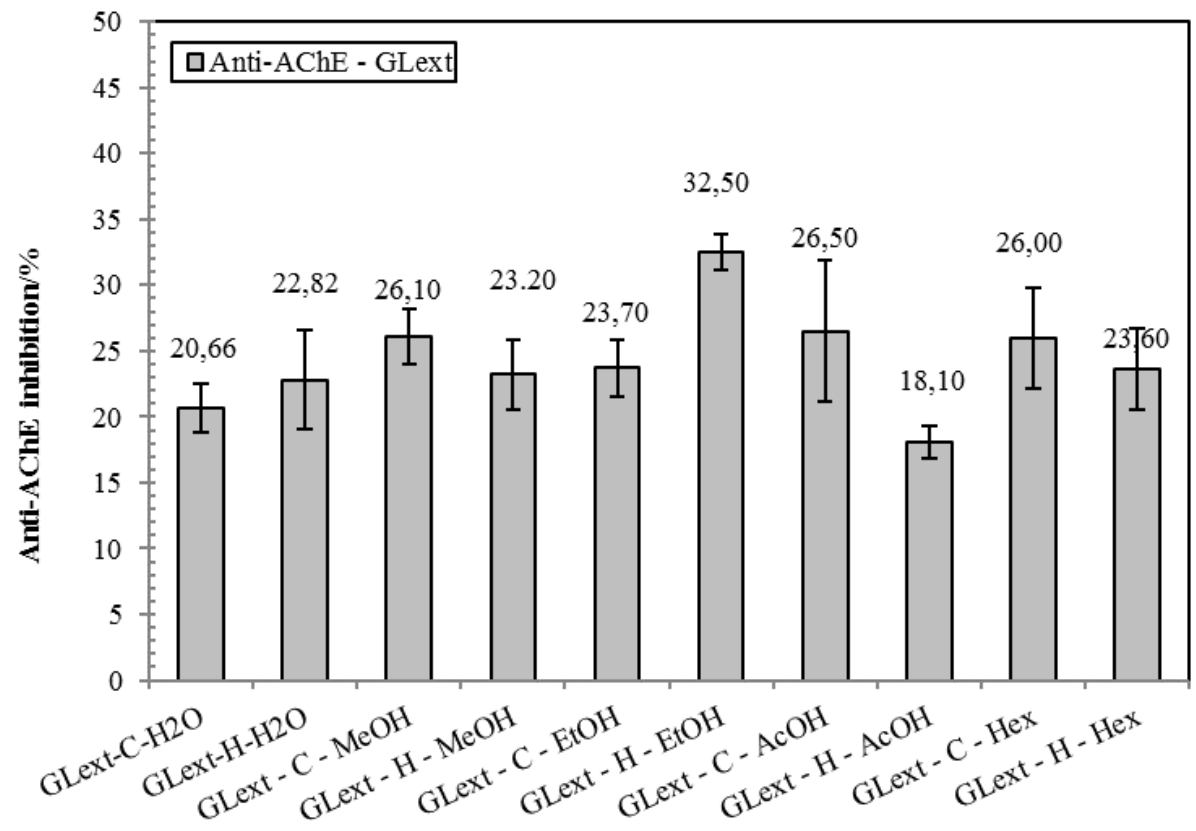

Fig. 5. Acetylcholinesterase ( $\mathrm{AChE}$ ) inhibitory activities of G. lucidum extracts $\left(\mathrm{GL}_{\text {ext. }}\right.$ ) obtained using hot (at boiling point of the solvent) / cold (at $\left.25^{\circ} \mathrm{C}\right)(\mathrm{H} / \mathrm{C})$ extraction solvent $\left(\mathrm{H}_{2} \mathrm{O}, \mathrm{MeOH}, \mathrm{EtOH}, \mathrm{AcOH}, \mathrm{Hex}\right)$. Data are expressed as percentage $(\%)$ of $\mathrm{AChE}$ inhibition. Data are means \pm SD from two replicates, where two independent experiments were performed. As a control inhibitor, galanthamine, which has an inhibitory activity of $95 \%$, was used.

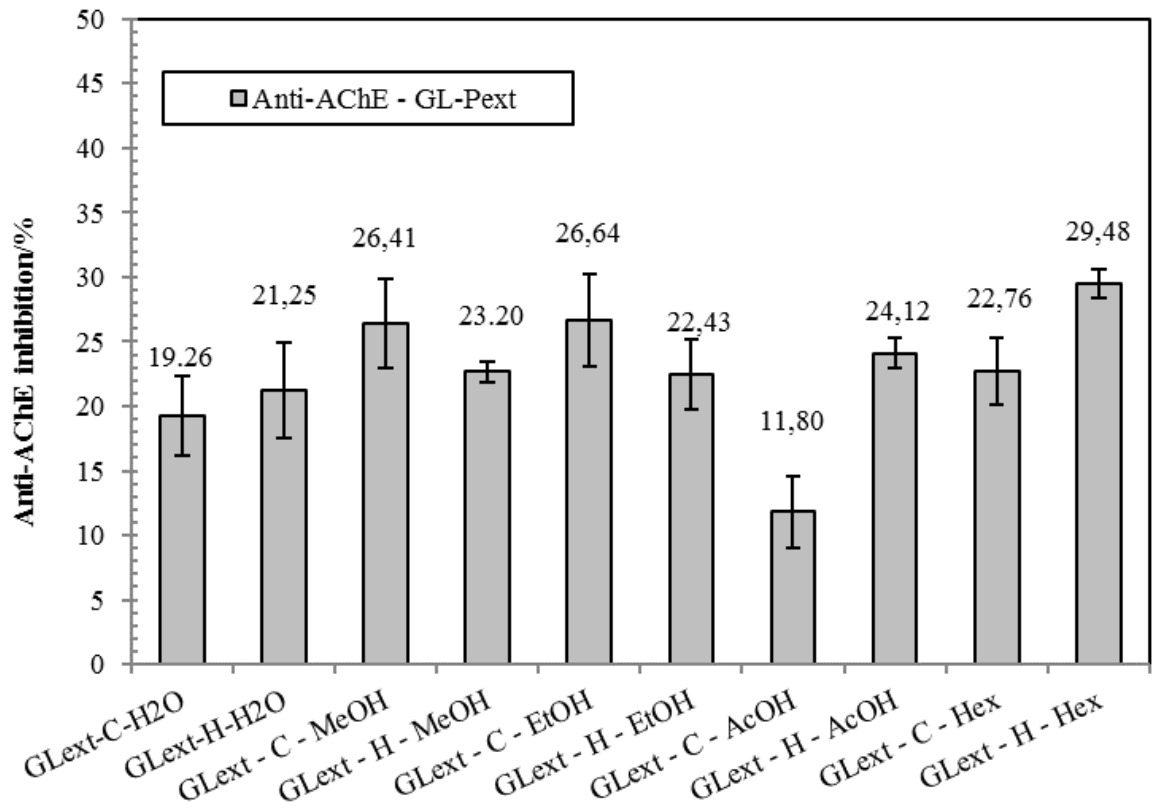

Fig. 6. Acetylcholinesterase (AChE) inhibitory activities of $G$. lucidum primordium extracts (GL- $\left.\mathrm{P}_{\text {ext }}\right)$ in $c=1 \mathrm{mg} / \mathrm{ml}$ obtained using hot (at boiling point of the solvent) / cold (at $\left.25{ }^{\circ} \mathrm{C}\right)(\mathrm{H} / \mathrm{C})$ extraction solvent $\left(\mathrm{H}_{2} \mathrm{O}, \mathrm{MeOH}, \mathrm{EtOH}, \mathrm{Ac}, \mathrm{Hex}\right)$. Data are expressed as the percentage (\%) of AChE inhibition. Data are means \pm SD from two replicates, where two independent experiments were performed. As a control, the inhibitor galanthamine was used, with an inhibitory activity of $94 \%$. 
The AChE inhibition of $\mathrm{GL}_{\text {ext. }}$ was between $18.1 \%$ for $(\mathrm{H}) \mathrm{AcOH}$ and $32.5 \%$ for $(\mathrm{H}) \mathrm{EtOH}$ (Fig. 5). A similar result was observed in the case of total phenol content (Fig. 1). Generally, the use of different solvents did not significantly affect AChE inhibitory activity. Furthermore, extraction temperatures did not greatly influence the $\mathrm{AChE}$ inhibitory activity of $\mathrm{GL}_{\text {ext }}$ (Fig. 5).

For primordia, the highest AChE inhibitory activity of $29.48 \%$ was obtained when GL- $\mathrm{P}_{\text {ext }}-\mathrm{H}-$ Hex was applied. The effect of solvents and/or extraction temperature is rather small; moreover, there is a correlation between the content of total phenols and AChE inhibitory activities.

There are no reports comparing AChE inhibitory activity of $\mathrm{GL}_{\mathrm{ext}}$ or GL-P $\mathrm{ext}_{\mathrm{ebtained}}$ with different solvents.

\subsubsection{Bioactivity of polysaccharides}

In both extraction procedures, GL and GL-P material was first pre-extracted with $\mathrm{MeOH}$ in order to remove phenolic compounds. Afterwards, the procedures described in section 2.2 were followed.

Total phenols, total polysaccharides, DPPH* free radical scavenging and AChE inhibitory activities were determined for all polysaccharidic extracts. As a control in AChE activity determination, the inhibitor galanthamine, with an inhibitory activity of $93 \%$, was used. The results are summarized in Table 2.

\section{Table 2}

Chemical content and bioactivity of polysaccharides obtained from G. lucidum fruiting body $\left(G L-P S_{\text {ext. }}-1 /-2\right)$ and primordia $\left(G L-P-P S_{\text {ext. }}-1 /-2\right)$ with two extraction procedures.

Data are means $\pm S D$ from two replicates, where two independent experiments were performed.

\begin{tabular}{lcccc}
\hline \hline Sample ID & $\begin{array}{c}\text { Total phenols } \\
\left(\mathrm{mg}_{\mathrm{GA}} \cdot \mathrm{g}_{\mathrm{ext}}{ }^{-1}\right) \pm \mathrm{SD}\end{array}$ & $\begin{array}{c}\text { Total polysaccharides } \\
\left(\mathrm{mg}_{\mathrm{GLC}} \cdot \mathrm{g}_{\text {Psext }}{ }^{-1}\right) \pm \mathrm{SD}\end{array}$ & $\begin{array}{c}\text { DPPH activity } \\
(\%) \pm \mathrm{SD}\end{array}$ & $\begin{array}{c}\text { Anti-AChE activity } \\
(\%) \pm \mathrm{SD}\end{array}$ \\
\hline GL-PS $_{\text {ext. }}-1$ & $8.48 \pm 1.67$ & $13.3 \pm 4.9$ & $20.46 \pm 2.19$ & $22.16 \pm 1.9$ \\
GL-PS $_{\text {ext. }}-2$ & $12.76 \pm 1.87$ & $15.9 \pm 5.4$ & $2.48 \pm 1.20$ & $18.66 \pm 1.3$ \\
\hline GL-P-PS $_{\text {ext. }}-1$ & $7.43 \pm 1.65$ & $16.36 \pm 1.19$ & $1.94 \pm 0.92$ & $14.39 \pm 4.1$ \\
GL-P-PS $_{\text {ext. }}-2$ & $10.44 \pm 2.43$ & $17.10 \pm 2.16$ & $0.90 \pm 0.50$ & $8.24 \pm 1.1$ \\
\hline \hline
\end{tabular}

Polysaccharide extract obtained using the first described method by Villares et al. had the highest amount of total phenols, $12.76 \mathrm{mg}_{\mathrm{GA}} \cdot \mathrm{g}_{\mathrm{ext}}{ }^{-1}$, as observed by other researchers [27]. Semi-purification can result in a lower polyphenol content in the extracts obtained. An additional purification step involved removal of phenols using $\mathrm{MeOH}$ from $G$. lucidum; this resulted in the lowest content of total phenols (GL-PS $\mathrm{ext}_{\mathrm{t}}-1$, Table 2). The polysaccharide content between GL-PS ext $-1 /-2$ did not change drastically (Table 2), indicating that purification steps did not result in a loss of polysaccharides during the extraction process from the initial G. lucidum material. The results of the present study show that the highest DPPH* activity of $20.46 \%$ was obtained for GL-PS $_{\text {ext }}$ -1 , with the lowest content of total phenols, indicating that purified G. lucidum extract has greater antioxidant activity than extract.

All polysaccharidic extracts displayed moderate AChE inhibitory activity between $18.66 \%$ and $22.16 \%$.

Both GL-P-PS ${ }_{\text {ext }}-1 / 2$ contained about 17 mg GLC per $g$ of GL-PS-P ${ }_{\text {ext }}$. The results of chemical analysis showed the presence of phenolic compounds in both extracts.
The purification step using $\mathrm{MeOH}$ resulted in the lowest content of total phenols (GL-P-PS ext -1 , Table 2).

In general, the results in Table 2 show that GL-PS $_{\text {ext }}$ from G. lucidum fruiting bodies have higher $\mathrm{DPPH}^{*}$ activity and higher anti-AChE activity compared with GL-P-PS ext $_{\text {from primordia. }}$ The amount of total phenols is higher in GL-P$\mathrm{PS}_{\mathrm{ext}}$ obtained from primordia.

\subsubsection{Bioactivity of proteins}

Extraction of proteins from G. lucidum fruiting bodies and primordia was performed as described by Villares et al. [27] using trifluoroacetic acid (TFA) for precipitation from crude hot water extract, pre-extracted with $\mathrm{MeOH}$. This procedure resulted in protein rich extract (GL-P $\mathrm{ext}_{\text {, }}$ GL-P-P $\mathrm{ext}_{\text {) }}$. Total protein and total phenol content, as well as $\mathrm{DPPH}^{*}$ and anti-acetylcholinesterase activities, were measured. The total protein content was measured using a method proposed by Bradford. The results of total phenols, total proteins, DPPH and anti-AChE activity for GL-P ext , GL-P-P ext $_{\text {are }}$ summarized in Table 3. 
T a ble 3

Chemical content and bioactivity of polysaccharides obtained from $G$. lucidum fruiting bodies $\left(G L-P_{\text {ext }}\right)$ and Ganoderma lucidum primordia $\left(G L-P-P_{\text {ext }}\right)$. Data are means $\pm S D$ from two replicates, where two independent experiments were performed.

\begin{tabular}{lcccc}
\hline \hline Sample ID & $\begin{array}{c}\text { Total phenols } \\
\left(\mathrm{mg}_{\mathrm{GA}} \cdot \mathrm{g}_{\mathrm{ext}}{ }^{-1}\right) \pm \mathrm{SD}\end{array}$ & $\begin{array}{c}\text { Total proteins } \\
\left(\mathrm{mg}_{\mathrm{BSA}} \cdot \mathrm{g}_{\mathrm{Pext}}{ }^{-1}\right) \pm \mathrm{SD}\end{array}$ & $\begin{array}{c}\text { DPPH } \\
(\%) \pm \mathrm{SD}\end{array}$ & $\begin{array}{c}\text { Inhibition of AChE } \\
(\%) \pm \mathrm{SD}\end{array}$ \\
\hline GL-P & $60.96 \pm 5.01$ & $13.3 \pm 4.9$ & $17.33 \pm 1.14$ & $24.40 \pm 1.36$ \\
GL-P-P & $26.04 \pm 4.94$ & $16.3 \pm 1.9$ & $3.35 \pm 0.55$ & $13.62 \pm 5.11$ \\
\hline \hline
\end{tabular}

From the results obtained, it can be observed that GL-P ${ }_{\text {ext }}$ contains $13.3 \%$ of proteins as well as a surprisingly high content of phenols of $60 \%$ (Table 3). Antioxidant and anti-AChE activities of GL$\mathrm{P}_{\mathrm{ext}}$, being $17.33 \%$ and $24.40 \%$, respectively, are probably the result of high phenol content.

Chemical analysis showed that GL-P-P $\mathrm{ext}$ contains $16.3 \%$ proteins and $26.04 \%$ phenols (Table 3). GL-P-P ext shows small DPPH activity, while AChE inhibitory activity was noticed with $13.62 \%$ inhibition. As a control inhibitor, galanthamine, which has an inhibitory activity of $88 \%$, was used.

The extraction procedure described resulted

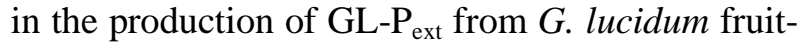
ing bodies. It is well recognized that phenolic compounds present in mushrooms may be complexed to soluble $\beta$-D-glucans by weak chemical linkages; therefore, the precipitation of proteins with TFA could result in the breakage of those links and the resulting high content of phenols in GL-P ${ }_{\text {ext }}$, as observed in the present study.

Polysaccharide and protein content from $G$. lucidum fruiting body and primordium also elicited antioxidant and acetylcholinesterase inhibitory activities.

The results indicate that the fruiting body and primordium of G. lucidum are rich in higher molecular weight phenolic compounds with strong DPPHfree radical scavenging activity and moderate $\mathrm{AChE}$ inhibitory activities. G. lucidum primordia and fruiting bodies potentially present a novel source of natural inhibitors of acetylcholinesterase enzyme.

\section{CONCLUSION}

The aim of our study was to investigate the antioxidant and acetylcholinesterase inhibitory activities of Ganoderma lucidum fruiting bodies and primordia extracts. To the best of our knowledge, this is the first report evaluating the biological activity of compounds extracted solely from $G$. $l u$ cidum primordia.
Extracts taken from G. lucidum fruiting bodies and primordia using various extraction procedures were characterized. Two different procedures were used for polysaccharide extraction and the extraction of proteins.

The extracted components proved to be very effective. In general, we conclude that the components of G. lucidum fruiting bodies as well as primordia are more polar than non-polar. The total phenol content is higher in the case of primordia extracts. The results indicate that fruiting body and primordia of G. lucidum are rich in higher molecular weight phenolic compounds with strong DPPH free radical scavenging activity and moderate $\mathrm{AChE}$ inhibitory activities. G. lucidum primordia and fruiting body present a novel potential source of natural inhibitors of acetylcholinesterase enzyme.

There are no reports on AChE inhibitory activity of $\mathrm{GL}_{\mathrm{ext}}$ or GL-P $\mathrm{P}_{\mathrm{ext}}$ obtained using other solvents. The ability to inhibit $\mathrm{AChE}$ is crucial in the development of Alzheimer's disease (AD). Since antioxidants play an important role in the protection against aging processes and neurodegenerative diseases such as $\mathrm{AD}$, the rate of inhibition of $\mathrm{AChE}$ was determined for $\mathrm{GL}_{\text {ext }}$ and GL-P $\mathrm{P}_{\text {ext }}$ extracts, which contain both polar and non-polar components with the capability of inhibiting AChE.

According to these results, both types of extracts present a potential source of compounds for slowing the aging and neurodegenerative processes.

Acknowledgments. The authors gratefully acknowledge the Slovenian Research Agency (Research Project J2-6750). The authors wish to thank Dr. Elena Markočič for editorial assistance with the manuscript.

\section{REFERENCES}

[1] S. Wachtel-Galor, J. Yuen, J. A. Buswell, I. F. F. Benzie, Ganoderma lucidum (Lingzhi or Reishi): A Medicinal Mushroom, in: I. F. F. Benzie, S. Wachtel-Galor (Eds.) Herbal Medicine: Biomolecular and Clinical Aspects, CRC Press, Boca Raton, 2011, pp. 175-192. 
[2] I. F. F. Benzie, S. Wachtel-Galor, Herbal Medicine: Biomolecular and Clinical Aspects, Second Edition, CRC Press, 2011.

[3] B. S. Sanodiya, G. S. Thakur, R. K. Baghel, G. Prasad, P. Bisen, Ganoderma lucidum: a potent pharmacological macrofungus, Curr. Pharm. Biotechnol. 10, 717-742 (2009).

DOI: http://dx.doi.org/10.2174/138920109789978757

[4] P. Batra, A. K. Sharma, R. Khajuria, Probing Lingzhi or Reishi medicinal mushroom Ganoderma lucidum (higher Basidiomycetes): a bitter mushroom with amazing health benefits, Int. J. Med. Mushrooms 15, (2013). DOI: 10.1615/IntJMedMushr.v15.i2.20

[5] H.-N. Zhang, J.-H. He, L. Yuan, Z.-B. Lin, In vitro and in vivo protective effect of Ganoderma lucidum polysaccharides on alloxan-induced pancreatic islets damage, Life Sci. 73, 2307-2319 (2003).

DOI: http://dx.doi.org/10.1016/S0024-3205(03)00594-0

[6] P.-F. Kao, S.-H. Wang, W.-T. Hung, Y.-H. Liao, C.-M. Lin, W.-B. Yang, Structural characterization and antioxidative activity of low-molecular-weights beta-1, 3glucan from the residue of extracted Ganoderma lucidum fruiting bodies, Biomed. Res. Int. 1-8, (2012). DOI: $10.1155 / 2012 / 673764$

[7] K. R. Li, A. Vasil'ev, A. Orekhov, V. Tertov, V. Tutel'ian, Anti-atherosclerotic properties of higher mushrooms (a clinico-experimental investigation), Vopr. Pitan. 16-19 (1988).

[8] A. S. Karwa, M. K. Rai, Naturally occurring medicinal mushroom-derived antimicrobials: A case-study using Lingzhi or Reishi Ganoderma lucidum (W. Curt.: Fr.) P. Karst.(higher Basidiomycetes), Int. J. Med. Mushrooms 14 (2012). DOI: 10.1615/IntJMedMushr.v14.i5.60

[9] W. Chen, S. Luo, H. Ll, H. Yang, Effects of Ganoderma lucidum polysaccharides on serum lipids and lipoperoxidation in experimental hyperlipidemic rats, China $J$. of Chinese Materia Medica 30, 1358-1360 (2005).

[10] A. A. Soares, C. G. M. de Souza, F. M. Daniel, G. P. Ferrari, S. M. G. da Costa, R. M. Peralta, Antioxidant activity and total phenolic content of Agaricus brasiliensis (Agaricus blazei Murril) in two stages of maturity, Food Chem. 112, 775-781 (2009). DOI: http://dx.doi.org/10.1016/j.foodchem.2008.05.117

[11] E. Cherian, N.P. Sudheesh, K.K. Janardhanan, G. Patani, Free radical scavenging and mitochondrial antioxidant activities of Reishi-Ganoderma lucidum (Curt: Fr) P. Karst and Arogyapacha-Trichopus zeylanicus Gaertn extracts, J. Basic Clin. Physiol. Pharmacol. 20, 289-308 (2009). DOI: 10.1515/JBCPP.2009.20.4.289

[12] C. Xiao, Q.-P. Wu, W. Cai, J.-B. Tan, X.-B. Yang, J.-M. Zhang, Hypoglycemic effects of Ganoderma lucidum polysaccharides in type 2 diabetic mice, Arch. Pharmacal Res. 35, 1793-1801 (2012). DOI:10.1007/s12272-012-1012-z

[13] Y. Gao, W. Tang, H. Gao, E. Chan, J. Lan, S. Zhou, Ganoderma lucidum polysaccharide fractions accelerate healing of acetic acid-induced ulcers in rats, J. Med. Food. 7, 417-421 (2004). DOI:10.1089/jmf.2004.7.417

[14] A. Dasgupta, K. Klein, Antioxidants in Food, Vitamins and Supplements: Prevention and Treatment of Disease, Academic Press, 2014.
[15] S. L. Albarracin, B. Stab, Z. Casas, J. J. Sutachan, I. Samudio, J. Gonzalez, L. Gonzalo, F. Capani, L. Morales, G. E. Barreto, Effects of natural antioxidants in neurodegenerative disease, Nutr. Neurosci. 15, 1-9 (2012). DOI: 10.1179/1476830511Y.0000000028

[16] L. H. Sanders, J. T. Greenamyre, Oxidative damage to macromolecules in human Parkinson disease and the rotenone model, Free Radical Biol. Med. 62, 111-120 (2013). DOI: $10.1016 /$ j.freeradbiomed.2013.01.003

[17] D. K. Lahiri, M. R. Farlow, N. H. Greig, K. Sambamurti, Current drug targets for Alzheimer's disease treatment, Drug Dev. Res. 56, 267-281 (2002). DOI: $10.1002 / \mathrm{ddr} .10081$

[18] S. Khatua, S. Paul, K. Acharya, Mushroom as the potential source of new generation of antioxidant: A review, Res. J. Pharm. Technol. 6, 496-505 (2013).

[19] P. Roupas, J. Keogh, M. Noakes, C. Margetts, P. Taylor, The role of edible mushrooms in health: Evaluation of the evidence, J. Funct. Foods 4, 687-709 (2012). DOI: http://dx.doi.org/10.1016/j.jff.2012.05.003

[20] L. Cheung, P. C. Cheung, V. E. Ooi, Antioxidant activity and total phenolics of edible mushroom extracts, Food Chem. 81, 249-255 (2003). DOI: $10.1016 / \mathrm{S} 0308-8146(02) 00419-3$

[21] M. Du, L. Zhao, C. Li, G. Zhao, X. Hu, Purification and characterization of a novel fungi Se-containing protein from Se-enriched Ganoderma lucidum mushroom and its Se-dependent radical scavenging activity, Eur. Food Res. and Technol. 224, 659-665 (2007). DOI: $10.1007 / \mathrm{s} 00217-006-0355-4$

[22] C.-H. Yeh, H.-C. Chen, J.-J. Yang, W.-I. Chuang, F. Sheu, Polysaccharides PS-G and protein LZ-8 from Reishi (Ganoderma lucidum) exhibit diverse functions in regulating murine macrophages and $\mathrm{T}$ lymphocytes, $J$. Agric. Food. Chem. 58, 8535-8544 (2010). DOI: $10.1021 / \mathrm{jf} 100914 \mathrm{~m}$

[23] M. A. Hasnat, M. Pervin, B. O. Lim, Acetylcholinesterase inhibition and in vitro and in vivo antioxidant activities of Ganoderma lucidum grown on germinated brown rice, Molecules 18, 6663-6678 (2013). DOI: $10.3390 /$ molecules 18066663

[24] D. Cör, T. Botić, Ž. Knez, U. Batista, A. Gregori, F. Pohleven, T. Bončina, Two-stage extraction of antitumor, antioxidant and antiacetylcholinesterase compounds from Ganoderma lucidum fruiting body, J. Supercrit. Fluids 91, 53-60 (2014). DOI: 10.1016/j.supflu.2014.04.006

[25] M. Oman, M. Škerget, Z. Knez, Application of supercritical fluid extraction for separation of nutraceuticals and other phytochemicals from plant material, Maced. $J$. Chem. Chem. Eng. 32, 183-226 (2013). DOI: http://dx.doi.org/10.20450/mjcce.2013.443

[26] Y. Chen, M. Xie, H. Zhang, Y. Wang, S. Nie, C. Li, Quantification of total polysaccharides and triterpenoids in Ganoderma lucidum and Ganoderma atrum by near infrared spectroscopy and chemometrics, Food Chem. 135, 268-275 (2012). DOI: 10.1016/j.foodchem.2012.04.089

[27] A. Villares, L. Mateo-Vivaracho, E. Guillamón, Structural features and healthy properties of polysaccharides occurring in mushrooms, Agriculture 2, 452-471 (2012). DOI:10.3390/agriculture2040452 
[28] K. Skalicka-Wozniak, J. Szypowski, R. Los, M. Siwulski, K. Sobieralski, K. Glowniak, A. Malm, Evaluation of polysaccharides content in fruit bodies and their antimicrobial activity of four Ganoderma lucidum (W Curt.: Fr.) P. Karst. strains cultivated on different wood type substrates, Acta Soc. Bot. Pol. 81, (2012).

DOI: http://dx.doi.org/10.5586/asbp.2012.001

[29] V. Singleton, J. A. Rossi, Colorimetry of total phenolics with phosphomolybdic-phosphotungstic acid reagents, Am. J. Enol. Vitic. 16, 144-158 (1965).

[30] M. M. Bradford, A rapid and sensitive method for the quantitation of microgram quantities of protein utilizing the principle of protein-dye binding, Anal. Biochem. 72, 248-254 (1976). DOI: 10.1016/0003-2697(76)90527-3

[31] M. Dubois, K. A. Gilles, J. K. Hamilton, P. Rebers, F. Smith, Colorimetric method for determination of sugars and related substances, Anal. Chem. 28, 350-356 (1956). DOI:10.1021/ac60111a017

[32] M. S. Blois, Antioxidant determinations by the use of a stable free radical, Nature 181, 1199-1200 (1958). DOI:10.1038/1811199a0

[33] G. L. Ellman, A. Burkhalter, J. LaDou, A fluorometric method for the determination of hippuric acid, J. Lab. Clin. Med. 57, 813-818 (1961).
[34] G. Lv, J. Zhao, J. Duan, Y. Tang, S. Li, Comparison of sterols and fatty acids in two species of Ganoderma, Chem. Cent. J. 6, (2012). DOI: 10.1186/1752-153X-6-10

[35] S.-Y. Tsai, S.-J. Huang, S.-H. Lo, T.-P. Wu, P.-Y. Lian, J.-L. Mau, Flavour components and antioxidant properties of several cultivated mushrooms, Food Chem. 113, 578584 (2009). DOI: 10.1016/j.foodchem.2008.08.034

[36] I. Orhan, O. Üstün, Determination of total phenol content, antioxidant activity and acetylcholinesterase inhibition in selected mushrooms from Turkey, J. Food Compost. Anal. 24, 386-390 (2011).

[37] S. A. Heleno, L. Barros, A. Martins, M. J. R. P. Queiroz, C. Santos-Buelga, I. C. F. R. Ferreira, Fruiting body, spores and in vitro produced mycelium of Ganoderma lucidum from Northeast Portugal: A comparative study of the antioxidant potential of phenolic and polysaccharidic extracts, Food Res. Int. 46, 135-140 (2012). DOI: 10.1016/j.foodres.2011.12.009

[38] G. Y. Celik, D. Onbasli, B. Altinsoy, H. Alli, In vitro antimicrobial and antioxidant properties of Ganoderma lucidum extracts grown in Turkey, European J. Med. Plants 4, 709 (2014). DOI:10.3390/molecules17043653

[39] J. De Bruijn, C. Loyola, P. Aqueveque, J. Cañumir, M. Cortéz, A. France, Antioxidant properties of extracts obtained from Grifola gargal mushrooms, Micol. Aplicada Int. 21, 11-18 (2009).

DOI:10.1155/2014/974804 
